\title{
Innovation in Teaching and Learning - Innover en enseignement - apprentissage
}

Jacinthe I. Pepin

Université de Montréal, jacinthe.pepin@umontreal.ca

Florence Myrick

amyrick@ualberta.ca

Follow this and additional works at: https://qane-afi.casn.ca/journal

Part of the Nursing Commons, and the Scholarship of Teaching and Learning Commons

\section{Recommended Citation}

Pepin, Jacinthe I. and Myrick, Florence (2017) "Innovation in Teaching and Learning - Innover en enseignement apprentissage," Quality Advancement in Nursing Education - Avancées en formation infirmière: Vol. 3: Iss. 1, Article 9. DOI: https://doi.org/10.17483/2368-6669.1125

This Interview is brought to you for free and open access by Quality Advancement in Nursing Education - Avancées en formation infirmière. It has been accepted for inclusion in Quality Advancement in Nursing Education - Avancées en formation infirmière by an authorized editor of Quality Advancement in Nursing Education - Avancées en formation infirmière. 
Innovation in Teaching and Learning

Interviewee: Dr. Olive Yonge, $R N, P h D, R P s y c h$

Interviewer: Dr. Jacinthe Pepin, Co-Editor-inChief

Dr. Jacinthe Pepin: Before we begin, I would like to take this opportunity on behalf of my CoEditor-in-Chief, Dr. Florence Myrick, and me to congratulate you on receiving the 2016 Pat Griffin Nursing Education Research Scholar Award and to thank you for agreeing to take the time for this interview.

Dr. Jacinthe Pepin: Dr. Yonge, can you describe what you view as the most rewarding and challenging aspects of being an innovator in nursing education?

Dr. Olive Yonge: To me, it is all about preparing a student to be the best nurse they can possibly be which means setting them up for success, making them feel confident and valued and proud to be a nurse. So my innovation is not about magic or show or gloss, it is always based on my values; what I really want to do as a nurse educator.

I believe in incremental innovation as much as grand ones. An example of a research innovation was the photo voice research we carried out. I was attending many qualitative conferences and every time they had a photo voice section, I always went to listen to presenters because I was fascinated with how you could use cameras to evoke and study meaning in people's lives. So, basically, the incremental innovation constituted giving cameras to rural preceptors and their students and asking them to take pictures of what teaching and learning is like in rural Alberta and Saskatchewan. It was fascinating because the answers were, "well hay bales are social determinants of health". If they receive a report that a farmer has been crushed by a hay bale, it means they have to prepare for spinal work to care for them given how heavy the hay bales are. The participants also took pictures of sunsets, canola fields, forests and river valleys, but we had just asked them about teaching and learning
Innover en enseignement - apprentissage

Invitée : $D^{r e}$ Olive Yonge, $R N, P h D, R P s y c h$

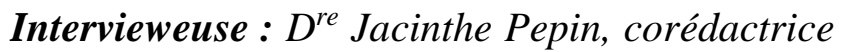
en chef

$D^{\text {re }}$ Jacinthe Pepin : Tout d'abord, j'aimerais profiter de l'occasion pour vous féliciter, en mon nom et en celui de la $\mathrm{D}^{\text {re }}$ Florence Myrick, corédactrice en chef, pour l'obtention du poste de recherche en formation infirmière Pat Griffin 2016, et vous remercier de prendre le temps de nous accorder cet entretien.

$D^{\text {re }}$ Jacinthe Pepin : $\mathrm{D}^{\text {re }}$ Yonge, quels sont à vos yeux les aspects les plus gratifiants et les plus difficiles d'innover en formation infirmière?

$D^{\text {re }}$ Olive Yonge : À mon sens, tout réside dans le fait de préparer les étudiantes à devenir les meilleures infirmières qu'elles puissent être, ce qui signifie de paver le chemin vers leur réussite et de faire en sorte qu'elles se sentent confiantes, valorisées et fières de leur profession. Pour moi, l'innovation n'a rien de magique ou de spectaculaire, mais repose plutôt sur mes propres valeurs, et relève de mes objectifs en tant que formatrice en sciences infirmières.

Je crois autant en l'innovation progressive qu'en celle de grande envergure. Un exemple d'innovation en recherche provient de nos travaux avec la méthode de la photovoix. J'ai participé à bien des conférences de recherche qualitative, et chaque fois qu'il y avait une session photovoix, j'allais écouter les présentateurs, fascinée par l'utilisation de caméras pour refléter le sens de la vie d'autrui et en faire l'étude. Essentiellement, notre innovation progressive consistait à donner des caméras aux préceptrices en milieu rural et à leurs étudiantes, puis à leur demander de prendre des photos de ce à quoi ressemblent l'enseignement et l'apprentissage dans les villages de l'Alberta et de la Saskatchewan. C'était captivant, car elles ont répondu : «Eh bien, les balles de foin sont des déterminants sociaux de la santé ». Si un rapport leur apprend qu'un fermier s'est fait écraser par une balle de 
in nursing. We came to understand that teaching and learning, particularly in the rural setting, is holistic. They cannot think about rural preceptorship as a silo; they have to think about all the variables. Context is a key aspect of teaching and learning and this is what they taught us. Had we used surveys or quantitative instruments we would have missed this rich data. We would have missed the implications, for example how to fully prepare students for rural experiences. Consequently as educators we not only have to consider the nursing competencies from our regulators, or the CASN outcomes for accreditation, but we also have to think beyond competencies.

I started Faculty Learning Communities (FLC) in our faculty. I went to a FLC American conference and subsequently introduced these communities to our Faculty. The first year I facilitated them with a research assistant. We always had food and kept minutes to help move the agenda. I scheduled them based on when faculty could attend and this was the biggest challenge for faculty. They are teaching so much of the time, clinical or seminars, they do not have much flex time, so any time faculty could get together, I formed them into groups. We started with the open ended question, "what do you think our FLC should look for and explore in nursing education?" They identified an array of different topics such as what does it mean when you have to fail a student or show can we create a more caring environment for everyone in the faculty? For the FLC who focused on the challenges of failing a student, we had a playwright and for many sessions she listened to us, and took notes. I was really struck by her notes of those meetings - there were so many insights generated by the faculty. She took those notes and wrote a play, which was then performed at a teaching and learning conference attended by nurse educators and graduate students. The performance and debriefing were incredibly moving. It emerged that a number of the participants were still living with the posttraumatic stress of having been threatened with failure or given negative feedback. It was healing to grasp what we were doing with students when we set them up for failure such as giving them foin, elles comprennent qu'elles doivent être prêtes à prodiguer des soins à une personne blessée à la colonne vertébrale, vu le poids des balles. Nous leur avons demandé des photos de l'enseignement - apprentissage en sciences infirmières; les participantes ont aussi pris des photos de couchers de soleil, de champs de canola, de forêts et de vallées fluviales. Nous avons alors compris que l'enseignement et l'apprentissage, particulièrement dans un environnement rural, s'avèrent holistiques. Elles ne peuvent pas envisager le préceptorat rural de manière isolée; elles doivent prendre en compte toutes les variables. Le contexte est un facteur clé de l'enseignement et de l'apprentissage, voilà ce qu'elles nous ont appris. L'utilisation de sondages ou d'outils quantitatifs n'aurait pas révélé ces riches données. Les implications nous auraient échappées, dont la manière de bien préparer les étudiantes pour les expériences de santé en milieu rural. Ainsi, en tant qu'éducatrices, nous devons non seulement viser les compétences infirmières exigées par nos organismes de réglementation, ou les résultats de l'ACESI en matière d'agrément, mais nous devons aussi penser au-delà des compétences.

J'ai mis sur pied des communautés d'apprentissage (Faculty Learning Communities, ou FLC) au sein de notre corps professoral. Je suis allée à une conférence américaine sur le sujet, puis j'en ai présenté le concept à mon retour. La première année, j'ai animé les rencontres avec une assistante de recherche; nous offrions toujours de la nourriture et rédigions des procès-verbaux afin d'assurer la progression des échanges. J'ai planifié ces activités selon les disponibilités du corps professoral, ce qui constituait un grand défi. Comme les membres du corps professoral enseignent la majeure partie du temps, soit en clinique ou en séminaire, leurs horaires ne sont pas vraiment flexibles. Donc, chaque fois que j'arrivais à en réunir en même temps, je formais des groupes. Nous sommes partis de la question ouverte : «Que pensez-vous que notre communauté d'apprentissage doit étudier en matière de formation infirmière? » Ils ont trouvé une variété de sujets, comme «qu'est que cela signifie de devoir faire échouer une étudiante », ou «comment créer un milieu 
feedback two days before the end of the clinical rotation, literally scaring them into failure. It goes back to being a professional, a professional nurse educator as much as a professional nurse. And when I hear student stories, stating, "I was blindsided" my heart just weeps because it should not be that way. Such experiences go back decades for all of us. We should be supporting, working and enabling each other. Yes there are power differentials between nurse educators and students, but there are ways of navigating those power differentials where you maintain your boundaries and you manage behaviours. Learning is a change of behaviour; you teach in such a way that the student feels empowered to do better versus scared of coming forward with their so-called naïve or inadequate, immature questions.

Dr. Jacinthe Pepin: How many faculty members participate in the Faculty Learning Communities that you have organized? Do you have more than one?

Dr. Olive Yonge: Yes. This year I have one and it is for all pre-tenure faculty. There are 15 faculty with whom I am meeting and so that FLC is focused on what you need to do to achieve tenure. For example we have sessions on how to prepare teaching, research and service dossiers. We have brought in faculty who already have tenure and they have told us their process of assembling their dossiers and application. We also had a simulated Faculty Evaluation Committee meeting and the FLC members observed and then asked questions based on the simulated review of three files. There tends to be a mystique about what really happens in that Faculty Evaluation Community and what you need to do to acquire tenure or to prepare for promotion.

Dr. Jacinthe Pepin: The Faculty Learning Community, as I understand it then, is that you provide one after the other and you concentrate on one specific topic, such as the one for tenure.

Dr. Olive Yonge: Yes, that is the topic I am addressing right now. Personally, I would love to see other faculty start FLCs. The person who started FLCs was Milton Cox (2013), and even now he is using the phrase Communities of bienveillant pour tous les membres du corps professoral ?» La communauté qui se concentrait sur les défis relatifs à l'échec d'étudiantes avait l'aide d'une dramaturge, qui nous a écoutées pendant de nombreuses séances tout en prenant des notes. J'ai été impressionnée par les notes prises lors de ces rencontres qui présentaient les idées perspicaces des membres du corps professoral. À partir de celles-ci, la dramaturge a écrit une pièce de théâtre qui a ensuite été jouée lors d'une conférence sur l'enseignementapprentissage devant un public d'enseignantes et d'étudiantes des cycles supérieurs. La performance et le débriefing qui a suivi étaient incroyablement touchants. Il s'est avéré que quelques participantes vivaient encore le stress post-traumatique de la menace d'un échec ou d'un commentaire négatif survenu par le passé. Cela était aidant de comprendre les répercussions pour les étudiantes, quand nous créons un environnement d'échec, par exemple en donnant de la rétroaction deux jours avant la fin des stages, les effrayant littéralement au point de les faire échouer. C'est une situation qui fait appel au professionnalisme, que ce soit en tant qu'infirmière enseignante ou infirmière tout court. Et quand j'entends les étudiantes raconter qu'elles n'avaient aucune idée, mon cœur fond en larmes, car ça ne devrait pas être ainsi. De telles expériences remontent à des décennies pour nous. Nous devrions nous soutenir, collaborer et nous enrichir les unes les autres. Bien sûr, il y a un déséquilibre de pouvoirs entre infirmières enseignantes et étudiantes, mais il y a moyen de naviguer ce déséquilibre où les limites ne sont pas dépassée et les comportements sont gérés. L'apprentissage constitue un changement de comportement : enseigner de sorte que les étudiantes se sentent capables de s'améliorer plutôt que craintives de poser des questions soi-disant naïves, inappropriées, immatures.

$D^{\text {re }}$ Jacinthe Pepin : Combien de membres du corps professoral ont participé aux communautés nées de votre initiative? Y en a-t-il eu plus d'une?

$D^{\text {re }}$ Olive Yonge : Oui. Cette année, il y a une communauté, réservée aux membres du corps professoral qui n'ont pas encore de permanence. 
Practice (CoP), which was first proposed by Wenger (1998). The idea is just to convene the faculty together on a consistent basis, delve deeply into an area, whatever that area may be and there is an obligation to have an outcome or product. Everyone must work toward the outcome. So the failing of the student was an example of one of the topics but the overarching theme was student satisfaction. I hold a Vargo Teaching Chair, so I could provide lunch or breakfast if need be, and I found that made a huge difference. Faculty are always running and when you can give them the opportunity to eat and sit and think, it really makes such a difference to them, and overall it's not much money. The product for the challenges of failing a student was a play that was performed.

Dr. Jacinthe Pepin: It is such a great idea. And what would you say are the challenging aspects of these examples of innovations that you gave?

Dr. Olive Yonge: My first nursing education innovation was when I was a very young faculty member who did not have tenure. The introduction of preceptorship had profound impacts on the Faculty and other Faculties and the clinical setting. In the early $80 \mathrm{~s}$ I was teaching psychiatric mental health nursing on a unit, and the unit was unusual. It had a huge boardroom, which served as our lunch room and report room, and all the disciplines convened there, so we were eavesdropping on each other. We could see what every discipline was doing and how they were talking and how they were acting. I noticed the psychiatrists were treating their young student interns with such respect. Some of the student interns were not happy being on a psychiatric unit for their experience but the senior psychiatrists really guided them. And as I was watching their interactions, I thought why we don't have our nurses teach our students the way the psychiatrists are teaching the interns. In psychiatry they do not have a clinical/medical educator who works with the students, they have a psychiatrist. And that is where it all started for me. I went to the unit supervisor, who supervised three units and I said what do you think? Should we try a pilot? Should we have your clinical nurses teach the students I'm now teaching? What do you think?
Je rencontre quinze enseignantes, et les séances portent sur ce qu'il faut faire pour obtenir sa permanence. Par exemple, nous abordons la préparation des dossiers d'enseignement, de recherche et de contribution. Des membres ayant obtenu leur permanence se sont jointes à nous pour partager le processus de monter leurs dossiers et de le soumettre. Nous avons également simulé une réunion du comité d'évaluation du corps professoral, où les participantes de la communauté ont observé et posé des questions selon l'examen fictif de trois dossiers. Un certain mysticisme plane autour de ce qui se passe réellement lors de cette évaluation et de ce qu'une personne doit faire pour obtenir sa permanence ou une promotion.

$D^{\text {re }}$ Jacinthe Pepin : Alors, si je comprends bien, la communauté vous permet de vous entraider en vous concentrant sur un sujet bien précis, comme la permanence.

$D^{\text {re }}$ Olive Yonge : Oui, c'est ce sur quoi je me penche en ce moment. Personnellement, je souhaiterais que d'autres corps professoraux démarrent des communautés d'apprentissage. C'est Milton Cox (2013) qui les a décrites, et il utilise encore le terme «communautés de pratique » $(\mathrm{CoP})$, d'abord proposée par Wenger (1998). L'idée consiste simplement à réunir un groupe de professeurs sur une base régulière et à creuser ensemble un sujet avec la visée obligatoire de produire un résultat. Tout le monde doit participer à l'atteinte de ce résultat. Ainsi, l'échec était un exemple de sujet, issu du thème général de la satisfaction des étudiantes. Je suis titulaire d'une chaire d'enseignement Vargo, ce qui me permettait d'offrir le déjeuner ou le dîner, au besoin. J'ai constaté que cela faisait une grande différence. Les enseignantes sont toujours à la course, et la chance de s'asseoir, de manger et de réfléchir peut leur apporter vraiment beaucoup, et sans débourser grandement, au final. Et le fruit de la réflexion sur les défis soulevés par l'échec d'étudiantes a été la présentation d'une pièce de théâtre.

$D^{\text {re }}$ Jacinthe Pepin : Quelle bonne idée! Et quels seraient les côtés plus difficiles de ces exemples d'innovation? 
And she said let's try it, so I wrote a proposal and we piloted it. All sorts of things were done to set this up for success. For example, 1 ensured the nurses who would work with the students were volunteers, and that they actually wanted to do this. There were given resources and taught how to preceptor. The students changed their clinical hours to conform to their preceptor which meant working evenings and nights and soon they formed close relationships. There were issues. Specifically, in western Canada, we have Registered Psychiatric Nurses, so we asked ourselves could they preceptor a student nurse in a baccalaureate program. Even though this nurse had tremendous experience and knew so much more than the baccalaureate nursing student, the question became, could you have a designated professional in nursing at a different level? This led to another question, could you have a nonnurse be the preceptor for the nursing student, or even could an interdisciplinary team member be the preceptor for the student? All of these questions arose as we worked it out. So when you are creating or starting with an innovation like that, I really love the saying "well begun is half done" and I was lucky, I talked to a lot of people about the idea who gave me feedback and it resulted in establishing a preceptorship program that is still used today.

Having said that though, in my own Faculty, when I submitted the idea through our approval processes, I had some resistance. I remember I was in the hallway, and one of the more senior nurse educators approached me, and she was clearly furious with me. At this point preceptorship had opened doors. Students could go anywhere in the world if I could negotiate it. So I was sending students to Banff, for example, and Jasper, because students were requesting these placements. Well Banff is a tourist haven, and this senior faculty member said to me "how dare you send a student to Banff? What can they learn in Banff about nursing?" I thought if there is a hospital in Banff, surely it is serving a purpose, and I would imagine they would have a lot of ortho in Banff. They would also have patients from the town site of Banff who would be having babies or health issues. I was shocked at her negativity and anger. Moreover, she just
$D^{\text {re }}$ Olive Yonge : J'ai réalisé ma première innovation en formation infirmière alors que j'étais très jeune professeure sans permanence. L'arrivée du préceptorat a eu des effets prononcés sur plusieurs corps professoraux ainsi que sur les milieux cliniques. Au début des années 1980, j'enseignais les soins infirmiers en santé mentale et psychiatrie au sein d'une unité peu commune. Elle possédait une immense salle de conférence, qui servait de salle à manger et de salle de présentation, où toutes les disciplines convergeaient, ce qui nous permettait de nous écouter les uns les autres. On pouvait alors voir ce que chacune des disciplines faisaient, comment ils parlaient et agissaient entre eux. J'ai remarqué que les psychiatres traitaient leurs jeunes stagiaires avec un grand respect. Si certaines étudiantes étaient mécontentes d'effectuer leur stage dans une unité psychiatrique, les spécialistes chevronnées les orientaient réellement. En observant leurs interactions, je me suis dit que nos infirmières devraient enseigner comme le font les psychiatres avec leurs stagiaires. En psychiatrie, il n'y a pas d'enseignante clinique/médicale pour travailler avec les étudiantes; c'est une psychiatre qui joue ce rôle. C'était le point de départ pour moi! Je suis allée demander l'avis de l'infirmière-chef d'unités (elle en gérait trois) : «Qu'en pensez-vous? Devons-nous mener un projet pilote? Vos infirmières cliniciennes devraient-elles enseigner aux étudiantes à qui j'enseigne présentement? Qu'en pensez-vous? » Ce à quoi elle a répondu: "Essayons, pour voir. » Puis, j'ai rédigé une proposition et nous en avons fait un projet pilote. Et beaucoup de choses ont été faites pour en garantir le succès. Par exemple, je me suis assurée que les infirmières qui travailleraient avec les étudiantes étaient des volontaires, et qu'elles voulaient vraiment participer. Des ressources leur ont été fournies et elles ont appris à agir en tant que préceptrices. Les étudiantes ont modifié leurs horaires de travail clinique pour s'adapter à leur préceptrice, ce qui signifiait pour elles de travailler le soir et la nuit. Elles ont rapidement tissé des liens étroits. Nous avons aussi rencontré des questionnements. Dans l'Ouest canadien, par exemple, il y a des infirmières psychiatriques autorisées, et nous nous sommes demandé si 
associated Banff as a tourist place. Certainly, the student wanted to go there and perhaps it was for more than a nursing practicum. I followed that placement with great interest, and it resulted in an excellent experience. So that is the kind of resistance I encountered.

I am always advocating for clinical education be it preceptorship or traditional. In Europe, you have entire nursing programs which are preceptored, and I was just changing one course. Some faculty embraced it immediately, and there is always the other extreme where there is resistance. Kotter (2012) explains this behaviour with his change theory. Today, preceptorship constitutes one-eighth of our curriculum, one term of the four years, and it is still going extremely well. But, it was also a cost-saving for the Faculty because at that point we had eight students in clinical and as soon as we had preceptorship we could increase it to 16; we have one faculty member support at least 16 students, which has cut our clinical teaching costs in half for that course.

There are other innovations I had to manage when I worked in central administration where faculty would propose an innovation that was truly an innovation, usually in the area of technology, and it would have a price tag of two or three million dollars. It is difficult when you see a highly innovative and expensive program, to determine if you could actually justify the cost, particularly in the area of technology. Technology just keeps changing. Technology that was just state of the art in 2017 could be obsolete by 2018. Meanwhile, you may have spent three million dollars. Innovation in the area of technology almost always has a price tag. But more importantly for me, the innovation has to reflect my values. Basically, whatever I am doing, whether it is preceptorship, FLCs, artsbased teaching or different kinds of assignments, it still goes back to the student. The student has to be enhanced by the innovation, the learning experience, and the engagement. The outcomes need to enhance the student learning experience. I cannot tolerate the thought of innovation for the sake of innovation. elles pouvaient être préceptrices pour les étudiantes au baccalauréat. Même si ces infirmières avaient une remarquable expérience et beaucoup plus de connaissances que les étudiantes, la question devenait: «Peut-on demander à une professionnelle en soins infirmiers d'enseigner à un niveau différent? » De cette question en découlait une autre : «Peuton demander à une personne qui n'est pas infirmière, voire à un membre d'une équipe interdisciplinaire, d'être la préceptrice d'une étudiante infirmière? » En fait, ces questions émergeaient dans le feu de l'action. Lorsque l'on se penche sur ce genre d'innovation, le proverbe « un travail bien commencé est à moitié achevé » me semble approprié. Je m'estime chanceuse car j'ai pu discuter de l'idée avec plusieurs personnes qui m'ont donné leur avis, le tout a permis d'établir un programme de préceptorat encore en place de nos jours.

Cela étant dit, lorsque j'ai soumis l'idée au processus d'approbation dans ma faculté, quelques barrières se sont dressées. Je me vois encore dans ce couloir, quand l'une des professeures les plus expérimentées s'est approchée de moi manifestement en colère. À ce moment, le préceptorat avait déjà ouvert des portes. Les étudiantes pouvaient aller partout dans le monde, si j'arrivais à le négocier. J'en envoyais à Banff, par exemple, et à Jasper, à la demande même des étudiantes. Évidemment, Banff est un havre pour touristes, et cette professeure m'avait alors interpelée: «Mais comment peux-tu envoyer une étudiante à Banff? Que peut-elle apprendre des soins infirmiers làbas? » J'ai pensé : «S'il y a un hôpital à Banff, cela doit être pour une raison, et j'imagine qu'ils doivent y faire beaucoup d'ortho. Ils doivent également recevoir des patients de la ville, des femmes qui accouchent ou des gens aux prises avec des problèmes de santé. » Son attitude négative et sa colère m'avaient laissée perplexe. Pour elle, Banff n'était qu'un lieu pour les touristes. Bien sûr, l'étudiante qui voulait s'y rendre avait peut-être d'autres visées que la pratique des soins infirmiers. J'ai suivi ce stage avec grand intérêt, qui a été une excellente expérience. Voilà donc le genre de résistance que j'ai rencontrée. 
Dr. Jacinthe Pepin: Dr. Yonge, how would you define "innovation"?

Dr. Olive Yonge: The typical innovation definition, and there are many of them, is that it is new and different, novel, creative, results in quality cost effectiveness or efficiency, and is achievable. If you cannot achieve innovation, it does not exist. You have to have it be achievable.

Innovation in nursing education is now linked to developing new curricula. Writers are talking about transformational curricula. The reasons cited for the need of a new curriculum are changes in society. I have witnessed many changes for example when I started teaching, we did not have anything called internationalization and now we have internationalization and globalization. Today we are looking at indigenous, and how many courses and content we need to include in this area. Evidence-based teaching and nursing scholarship are terms that are now being used. I have always appreciated evidence-based teaching and in my course outlines, I am looking for and critiquing the very best evidence-based research articles for teaching and learning. Early in my career I did two systematic reviews: one in the area of nursing education and the other in my clinical area of psychiatric mental health nursing. In the area of nursing education we generated an inventory of teaching and learning articles and there were some that were just one offs, and that bothered me a lot-they did not seem to go anywhere.

Now we speak of ethics and ethical decision making because of the complexity of care. When SARS occurred I was in central administration at the university and it became a real issue for us. It raised so many challenges. I was chair of the committee responsible for writing the pandemic plan. We had five ethical principles that guided our decision-making-such as openness, transparency. One of the committee members said "for any project or task force that we undertake, we should all think and talk about the ethical principles we will use for this task force," and I so appreciated this insight from that faculty member. How often do we do this? We just
Je promeus sans cesse la formation clinique sous forme de préceptorat ou dans son format traditionnel. En Europe, des programmes entiers de soins infirmiers fonctionnent sous forme de préceptorat, et moi, je ne modifiais qu'un seul stage. Quelques professeures ont immédiatement accueilli l'idée, et comme pour toutes choses, certaines se sont opposées. Kotter (2012) explique cette opposition dans sa théorie sur le changement. Maintenant, le préceptorat occupe un huitième de notre programme, soit un trimestre sur quatre ans, et tout se passe admirablement bien. La faculté a également économisé de l'argent, car à l'époque, nous avions huit étudiantes en formation clinique à la fois, un chiffre qui est passé à seize grâce au préceptorat; une seule enseignante s'occupe de seize étudiantes, réduisant les coûts de formation clinique de moitié pour ce stage.

J'ai eu d'autres innovations à gérer lorsque je travaillais dans l'administration centrale. Une faculté proposait une idée, une véritable innovation, la plupart du temps dans le domaine de la technologie, accompagnée d'une facture de deux ou trois millions de dollars. C'est difficile, même pour un programme très novateur et dispendieux, d'établir une réelle justification de tels coûts, en particulier dans ce domaine. La technologie est en constante évolution. Le nec plus ultra en 2017 peut être désuet l'année suivante. Chemin faisant, il s'est peut-être dépensé trois millions de dollars. L'innovation, dans le secteur technologique, a presque toujours un prix. Mais ce qui compte le plus à mes yeux, c'est de véhiculer mes valeurs par l'innovation. Essentiellement, peu importe ce que je fais, que ce soit le préceptorat, les communautés d'apprentissage, l'enseignement fondé sur les arts ou toute autre activité, tout revient aux étudiantes. Elles doivent pouvoir bénéficier de l'innovation, de l'expérience d'apprentissage et de l'engagement. Les résultats doivent améliorer leur expérience d'apprentissage. Je ne peux supporter l'idée d'innover pour innover.

$D^{\text {re }}$ Jacinthe Pepin : $\mathrm{D}^{\text {re }}$ Yonge, quelle est votre définition de «l'innovation »?

$D^{\text {re }}$ Olive Yonge : Selon la définition classique, et il $\mathrm{y}$ en a plusieurs, une innovation est une 
don't. We start, "oh, how are we going to do this" and we just proceed. We do not always think about the ethical principles on which our work is based. And, as it turned out, we did have a variety of ethical dilemmas. For example, regarding the pandemic, we were dealing with the avian flu at that time. The question arose, should we provide N95 masks to all staff, regardless of their previous health history? And we thought ethically, all our workers should have these masks. And then I read there were certain businesses that would not give, or spend the money on the N95 mask if an employee had a pre-existing health condition such as asthma. These business leaders felt that if you were exposed to the virus, and you had this preexisting health condition, you were a poor risk. They were going to give the best resources to the fittest in their organization. We did not take this approach and this was based on the formation and acceptance of our ethical principles.

We have to have a lot more planned community integration between education facilities and community/ health care agencies. These agencies be they health care or not, have to be part of our educational community. We need to have a different philosophy of integration with the community and how we are working together. Basically, I think the changes that are driving society right now call on us as nurse educators to think differently, to be part of bigger and larger conversations. We invited Dr. Afaf Meleis to be part of our 25th anniversary for our doctoral program, and she talked about Penn State having four pillars for their new curriculum, and one of the pillars was "student voice." Voice means giving high quality presentations to participating toast masters for students. There is also the student voice of advocacy, the student voice of critique, of being involved in local government, or in the political process, understanding how systems work and organizations work. Where do they have a voice in curriculum? The other side of voice is the one whereby some students will make demands and say "this is the way it should be for me," and thus misconstrue voice for another form of communication.

No matter what you are doing in the area of innovation and change, there is always that chose nouvelle, différente, originale, créative, rentable, efficace et réalisable. Si l'innovation ne peut être mise en œuvre, ce n'en est pas une. Il est crucial de pouvoir la réaliser.

En formation infirmière, cela se traduit maintenant par l'élaboration de nouveaux programmes. Les auteurs parlent d'ailleurs de «programmes transformationnels ». Selon eux, ce besoin découle des changements au niveau de la société. J'ai été témoin de bien des changements. Par exemple, quand j'ai commencé à enseigner, personne ne parlait d'internationalisation ou de mondialisation. Aujourd'hui, ces deux notions sont bien réelles. Nous nous tournons vers les autochtones et décidons du nombre de cours et de contenu à intégrer. La formation basée sur les résultats probants et l'avancement des connaissances en sciences infirmières sont maintenant des notions courantes. J'ai toujours aimé la formation basée sur des résultats probants et dans mes plans de cours, je cherche à introduire et analyser les meilleurs articles de recherche possible sur l'enseignement - apprentissage. En début de carrière, j'ai fait deux revues systématiques des écrits: l'une dans le domaine de la formation infirmière, l'autre dans mon secteur de soins infirmiers en santé mentale et psychiatrie. En formation infirmière, nous avons dressé une bibliographie des articles sur l'enseignement apprentissage. Certains, ponctuels, me fatiguaient énormément, car il me semblait qu'aucune suite n'était donnée.

Il est maintenant question d'éthique et de prise de décision éthique, en raison de la complexité des soins. Quand est survenu l'épisode du SRAS, j'étais dans l'administration de l'université, et c'est devenu un véritable enjeu pour nous. Les défis se sont multipliés. J'étais présidente du comité responsable de la rédaction du plan d'intervention en cas de pandémie. Cinq principes éthiques ont orienté notre prise de décision, dont l'ouverture et la transparence. L'un des membres du comité a proposé : «Pour chaque projet ou groupe de travail initié, nous devrions toujours penser aux principes éthiques qu'on souhaite appliquer, et en discuter », une sage suggestion que j'ai grandement appréciée. Et combien de fois adoptons-nous une telle 
human element, that human factor where it is not just what you want it to be. It is what it is and what will be, and you need skills to manage change, to be clear on your boundaries and to be able to risk failure. If the change was totally safe, it is likely that it would be low on an innovation scale.

To have innovation, to make it sticky, you have to have alliances. The best alliance I had was with Dr. Flo Myrick-she came to me and wanted to do her doctoral work in preceptorship. I was so thrilled, and because as a doctoral student, we were able together to establish evidence for preceptorship. After she graduated, we took the time to conceptualize our program of research, to pilot and explore the issues. Our program was successful because of funding we received from SSHRC and even more doctoral students who were interested in preceptorship or related areas like mentorship. Dr. Myrick began her research career examining critical thinking in undergraduate nursing students and the next question was examining critical thinking in preceptored graduate students. We have had so many students who had worked in some aspect of preceptorship from studying Aristotle's work on practical wisdom, to rural preceptorship, exploring the boundaries of preceptorship when preceptors have to fail students and two studies in the area of interdisciplinary preceptorship: conflict and developing a tool. All the other disciplines in the health care system use a form of preceptorship: mentorship, field teaching in education or clerkship. I would really like to stress it took time for this innovation called preceptorship to evolve; we had to nail it down, peg by peg, to really explore and establish the evidence for it.

We are changing our curriculum, and I am leading a research team using developmental evaluation to provide the evidence for the new curricular decisions. We are interviewing students, faculty, external stakeholders professional association, union, many student placement sites), asking the participants what attributes our graduate should possess, what changes needs to be made to the curriculum etc. It has been a big undertaking. We are generating reports with numerous recommendations. As I approche? Jamais. Nous commençons par: «Alors, comment allons-nous procéder? » Puis, nous agissons. Nous ne réfléchissons pas toujours aux principes éthiques qui régissent notre travail. Mais en fait, nous avons été confrontés à divers dilemmes éthiques au fil du temps. Revenons à l'exemple de la pandémie de SRAS, qui coïncidait avec la grippe aviaire. Nous nous sommes demandé si nous devions fournir des masques N95 à tout le personnel, sans égard à leurs antécédents de santé. Du point de vue éthique, avons-nous pensé que toute travailleuse devrait porter un masque. J'ai par la suite lu que certaines entreprises ne donnaient pas de masque N95 à toute employée qui présentait un trouble de santé connu, comme l'asthme, ou alors refusaient d'en assumer les frais. Ces dirigeants d'entreprise estimaient que si une personne exposée au virus avait déjà un problème connu, elle constituait un mauvais risque, et ils préféraient distribuer les ressources dans leur organisation selon la loi du plus fort. Nous n'avons pas adopté cette approche, grâce à la création et à l'acceptation de nos principes éthiques.

Nous devons favoriser l'intégration planifiée des communautés des infrastructures d'enseignement et des organismes communautaires/de soins de santé. Qu'ils s'occupent ou non de santé, ces organismes doivent joindre notre communauté de formation. Nous devons adopter une nouvelle philosophie d'intégration à la communauté dans son sens large et de collaboration. Essentiellement, je crois que les changements affectant actuellement la société nous invitent, en tant qu'infirmières enseignantes, à penser différemment et à élargir nos cercles de discussion. Nous avons invité la $\mathrm{D}^{\text {re }}$ Afaf Meleis à prendre part au $25^{\mathrm{e}}$ anniversaire de notre programme de doctorat. Elle y a expliqué que le nouveau programme de Penn State comprend quatre piliers, l'un d'eux se rapportant à la « voix des étudiantes ». Cette « voix » consiste à offrir aux étudiantes l'occasion d'entendre de leaders et présentateurs publics de qualité supérieure. Elle concerne également la voix de la défense des intérêts, de la critique, de l'implication dans le gouvernement ou le processus politique local, ainsi que la compréhension du fonctionnement 
alluded to, it is referred to as "developmental evaluation," and it emanates from the work of Patton (2012) who is an evaluator. He was working with a particular agency, and those in the agency said to him "we love the work, we love your suggestions, your recommendations for change, but are you now leaving us, is that it?" and he said "no, I will come back and I will see if you have actually implemented my recommendations." So that is why it is called developmental evaluation. Now, he acknowledges that he made a mistake; in his writings, he should have called it adaptive evaluation, not developmental. However the term caught on and it is now referred to as developmental. So in six months to one year, we will be going back (the reports go to the Dean, the Vice-Dean, and the Associate Dean Undergraduate). We are going to go back and say "okay, these were the recommendations we have generated, what you have been doing regarding the recommendations?" Plus as the reports have been released, changes are already being made. The admin team has responded illustrating their decisions with a chart, illustrating our recommendations on one side and what they are doing on the other side. The process is working. It is a great idea to have research evidence for the new curriculum.

I have a doctoral student working with me who has been terrific, especially when conducting focus groups. We wrote an abstract focusing on developmental evaluation as a method to present at a nursing education conference, and as we have been preparing, we have not found articles in nursing or in nursing education about the application or use of developmental evaluation. This is a bit of a puzzle for us since other disciplines have embraced this method. I did not think of this work as innovative. I just thought of it as common sense and a good base for curricular reform.

Dr. Jacinthe Pepin: This is quite interesting, and I would suspect that faculty, who do use developmental evaluation during curriculum change, do not necessarily publish on it. That may be one reason why you did not find many research articles. des systèmes et des organisations. Où la voix étudiante s'exprime-t-elle dans le programme? Une autre facette de cette voix se manifeste lorsque des étudiantes émettent des demandes en disant: "voilà comment les choses devraient être pour nous ». Et c'est là qu'elles confondent la «voix» avec une autre forme de communication.

Peu importe ce que l'on fait dans le domaine de l'innovation et du changement, le facteur humain est toujours présent, mais pas comme on pourrait le souhaiter. Il est comme il est, et comme il sera toujours. Cela prend certaines aptitudes pour gérer le changement, établir clairement ses limites et affronter le potentiel d'échec. Un changement complètement sûr serait probablement au bas de l'échelle de l'innovation.

Pour réaliser une innovation, la faire adhérer, il faut créer des alliances. Ma meilleure alliée a été la $\mathrm{D}^{\text {re }}$ Flo Myrick; elle m'a approchée dans le but de faire sa thèse de doctorat sur le préceptorat. J'étais vraiment emballée, car avec cette thèse, nous pouvions toutes les deux soutenir le préceptorat avec des résultats de recherche. Une fois diplômée, elle s'est jointe à moi pour conceptualiser notre programme de recherche, et pour tester et étudier les questions y étant soulevées. Notre programme a été un succès en raison du financement offert par le Conseil de recherches en sciences humaines (CRSH) et d'autres étudiantes au doctorat intéressées par le préceptorat ou des domaines liés, comme le mentorat. $\mathrm{D}^{\mathrm{re}}$ Myrick a débuté sa carrière de chercheuse en examinant la pensée critique des étudiantes en sciences infirmières de premier cycle puis elle s'est intéressée à celle des diplômées ayant bénéficié du préceptorat. Tellement d'étudiantes ont travaillé sur un aspect ou un autre du préceptorat: l'étude des travaux d'Aristote sur la sagesse pratique, le préceptorat en milieu rural, l'exploration des limites de la méthode (soit quand une préceptrice doit faire échouer quelqu'un). Nous avons aussi mené deux études dans le domaine du préceptorat interdisciplinaire : le conflit et l'élaboration d'un outil. En effet, toutes les autres disciplines du système de santé utilisent une forme de préceptorat, que ce soit le mentorat, l'enseignement pratique en éducation ou le stage 
Dr. Olive Yonge: Yes, you're right.

Dr. Jacinthe Pepin: They might think it is not part of a research process; it helps build their curriculum. It is a hypothesis.

Dr. Olive Yonge: Yes, I need to explore this more. I'm in the early stages of thinking about it.

Dr. Olive Yonge: For faculty, ensure your new idea is actually innovative. It is great to talk about it, but you have to read/know the literature, attend conferences, know the basics, and know what actually exists in this area. It might be innovative to you because you have not previously discovered this idea in the literature. Do the groundwork; explore the concepts or issues, which in turn will help save a lot of time for you and others. I was attending a conference last year and was watching these two presenters introduce a new staffing model in the clinical area. I had such a hard time listening, because it was not new or innovative. In fact, I had been part of that staffing model myself years ago. A person needs to delve into the history of nursing and read some earlier articles, not just the ones published in the last decade. We tend to read the most recent articles given the explosion on nursing research articles. Librarians are excellent resources on how to streamline searches.

Sometimes you have to walk away. You could have an innovative idea, and it is a really good one, but it could be too expensive, the culture is not conducive or you do not have the timeparticularly if you as the lead are endeavoring to acquire tenure. Sometimes the culture has to be created first so that it becomes fertile for the innovation. The other cultural issue is to build an ethos of innovation which is where you need to take a risk, risk potential failure and try things that actually do not really work out. If you do not have that kind of attitude you will always be too safe or too conservative, but again, it is bigger than you; it is the whole culture of the faculty that you need to consider.

Dr. Jacinthe Pepin: This is a fine line that you're describing here.

\section{Dr. Olive Yonge: Yes!}

Dr. Jacinthe Pepin: And knowing that, before you decide to walk away, you need to know if clinique. J'aimerais vraiment insister sur le fait que l'évolution de l'innovation nommée «préceptorat » a pris du temps. Nous avons dû la cerner, étape par étape, pour vraiment l'explorer et la documenter.

En vue de fournir des données qui guideront les décisions touchant la transformation de notre programme, je dirige une équipe de recherche qui se sert de l'évaluation de développement comme méthode. Nous menons des entretiens avec les étudiantes, les membres du corps professoral et les intervenants externes (associations professionnelles, syndicats et divers milieux de stages) pour leur demander quelles qualités doivent posséder nos diplômées, quels changements doivent être effectués dans notre programme, etc. C'est une entreprise d'envergure. Les rapports qui en découlent débordent de recommandations. Comme je l'ai mentionné, il s'agit de l'«évaluation de développement ", issue des travaux de Patton (2012), un spécialiste de l'évaluation. Il collaborait avec un organisme, et les gens y travaillant lui ont dit: "Nous aimons votre travail, vos suggestions et vos recommandations de changement, mais vous nous quittez à présent, c'est tout? » Ce à quoi il a répliqué : «Oh non, je vais revenir pour voir si vous avez appliqué mes idées. » Voilà pourquoi cela s'appelle de l'évaluation de développement. Il avoue aujourd'hui avoir commis une erreur: dans ses écrits, il aurait plutôt dû utiliser le terme «évaluation adaptative». Cependant, le terme choisi s'est cristallisé et est toujours d'usage. Donc, d'ici six mois à un an, nous y retournerons (les rapports sont soumis à la doyenne, à la vicedoyenne et à la doyenne associée du programme de premier cycle). Nous irons les voir et leur demanderons : «Alors, qu'avez-vous fait de nos recommandations? » En fait, des changements s'effectuaient déjà au moment de publier les rapports. L'équipe de direction a illustré ses décisions au moyen d'un tableau montrant nos recommandations d'un côté et les mesures entreprises de l'autre. Le processus fonctionne. C'est une excellente idée de se servir de résultats de recherche pour le nouveau programme.

Une de mes étudiantes au doctorat, avec qui je collabore, a été sensationnelle, surtout pour 
the culture is a fertile context for your innovation. But at the same time, you are suggesting that you need to build that culture and be innovative and bold and go ahead with it. This is a fine line; can you talk a little bit more about that?

Dr. Olive Yonge: Yes, it is a fine line. I am going to go back to being a student nurse. I was in a hospital (diploma) and then came back and completed my BSc. During my hospital diploma program, it did not take me long to determine that the charge nurse or head nurse made or broke their nursing unit based on their beliefs, values, role modeling, and directives. As a nursing student, you went from unit to unit and immediately, you could detect what kind of unit it was. Then later on when I attended university I funded myself through working casual or floating. I quickly learned to ask if the med keys were hidden or carried by someone and secondly, what was expected of me. Again, I found that from unit to unit there was such a difference. The difference for me was leadership. The Director of Nursing for the hospital was the same person but the charge nurses were all different. They had very different nuances in expression of their leadership. When I think about a culture for a Faculty of Nursing, I think the culture is created by all of us, we are all leaders but the administration of the Faculty is critical. The Dean creates conditions for safety when we fail (praising rather than shaming) during the Faculty Evaluation Committee process. Faculty need to be guided, coached and if there is going to be a culture of innovation. I believe if you have an administrative team in a Faculty who have a growth versus fixed mind set (Dweck, 2006) innovation happens. When I started the preceptorship program I had the right Dean for me. She saw it, and she said "keep going, keep going with what you're doing." Had she said to me, this is never going to work, the faculty are too resistant, I would have stopped. I mean, I would not have been able to continue without that Dean or the admin team's support.

Dr. Jacinthe Pepin: And that would be the walk-away?

Dr. Olive Yonge: That would be the walk away. diriger les groupes de discussion. Nous avons écrit une proposition de communication sur la méthode d'évaluation de développement, pour présenter lors d'une conférence sur la formation infirmière, et ce faisant, nous n'avons pas trouvé d'articles sur l'application ou l'utilisation de cette méthode en sciences infirmières ou en formation infirmière. Cela nous a étonnées puisque d'autres disciplines l'ont adoptée. Je n'aurais pas qualifié ce projet d'innovateur. J'y voyais seulement du bon sens, ainsi qu'une base solide de réforme du programme.

$D^{\text {re }}$ Jacinthe Pepin : C'est très intéressant. Je présume que les facultés, qui ont utilisé cette approche d'évaluation pour transformer leur programme, n'ont pas publié à ce sujet. Voilà peut-être pourquoi vous n'avez pas trouvé d'articles de recherche.

$D^{\text {re }}$ Olive Yonge : Oui, vous avez raison.

$D^{\text {re }}$ Jacinthe Pepin : Elles pensent peut-être que cela n'entre pas dans le processus de recherche, que cela aide seulement à bâtir leur programme. J'émets une hypothèse.

$D^{\text {re }}$ Olive Yonge : Oui, je dois y songer davantage. Je suis encore en début de réflexion.

$D^{\text {re }}$ Olive Yonge : En ce qui concerne le corps professoral, il faut s'assurer que l'idée proposée est vraiment novatrice. C'est bien d'en parler, mais il faut connaître les écrits sur le sujet, assister à des conférences, maîtriser les bases et savoir ce qui se fait concrètement dans le domaine. Une idée peut vous sembler novatrice parce que vous ne l'avez jamais rencontrée dans vos lectures. Mais vous devez vous préparer, explorer les concepts ou les questions, ce qui en retour vous fera économiser beaucoup de temps, à vous et aux autres. L'an dernier, j'assistais à une conférence où deux animateurs présentaient un nouveau modèle de recrutement dans le secteur clinique. J'avais tant de difficulté à les écouter, car l'idée n'avait rien de nouveau ni d'audacieux. Pour tout dire, j'y avais moi-même participé il y a des années. Nous devons creuser l'historique en sciences infirmières et lire quelques articles moins récents, pas seulement les publications de la dernière décennie. Nous avons tendance à nous en tenir aux articles les plus récents, vu la multiplication d'articles de 
Dr. Jacinthe Pepin: So far you have mentioned two suggestions for innovation: first do the ground work, and then know when to walk away or to be bold and keep going. Any other suggestions?

Dr. Olive Yonge: Be strong. Push yourself. Take risks, and float with failure. In business, they have these entrepreneurs, and they tend to fail. Some of them are so successful, but they are always, moving from idea to idea, and asking what about this or what about that? And in some ways, we need more of that attitude in our own profession. More questioning, more curiosity. Some of our ideas, when we generate so many of them, are going to be duds, failures. And we have to have a culture that says that is okay. Just keep asking, keep thinking which goes back to that culture of supporting each other and not being hard on each other.

We need to open doors for each other through sponsorship or mentorship or just offering to help each other. It is critical to show gratitude or appreciation and to acknowledge those in the faculty who are having a hard time. I was lucky to work on a unit of 35 staff and we went out of our way to give little gifts to each other, little encouragements, and little sayings. Not all the time of course, but we were always trying to think about watching each other's back, and I don't know if you were raised with this philosophy, but I sure was: work on your weaknesses. If you have strengths, work on your weaknesses. In this unit we did not do that-we only worked on our strengths. My weakness, something I do not like to do, hopefully for someone else, that will be their strength. Do not worry about it-just focus on your strengths. I really found it liberating, or freeing, because it gave me permission to brainstorm, to say "what about this, or what about that?" And the safety of the team to tell me, "Olive, that's a great idea," or "Olive, that will never work. And these are the reasons why that won't work." And I would, out of respect, say, "oh, okay, good. Thank you for the feedback." Rather than watching me walk off the cliff and fall, they intervened and said "this is what you've got to do now." And I did the same thing with other members. I too, saw things. Virginia Satir, a social worker, said: "I recherche en sciences infirmières. Les bibliothécaires sont excellentes pour faciliter le repérage.

Et parfois, il faut abandonner. On peut avoir une idée novatrice, et une vraie bonne idée, mais il se peut que son coût soit trop élevé, que la culture n'y soit pas favorable ou que le temps manque, en particulier si on la porte tout en tentant d'obtenir sa permanence. Il faut parfois créer une culture d'abord afin d'y semer l'innovation. L'autre difficulté en lien avec la culture consiste à établir une philosophie de l'innovation, et c'est là qu'il faut prendre un risque, celui d'échouer et d'essayer des choses qui ne fonctionnent pas vraiment, en réalité. Si une personne n'a pas ce genre d'attitude, elle sera toujours trop confortable ou conservatrice. Mais voilà tout : l'idée dépasse la personne, c'est à l'échelle du corps professoral qu'il faut envisager la culture.

$D^{\text {re }}$ Jacinthe Pepin : C'est une bien mince ligne que vous décrivez là.

\section{$D^{\text {re }}$ Olive Yonge : Oui!}

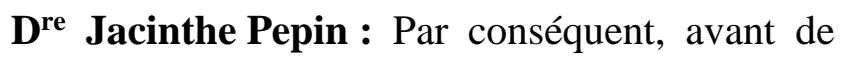
décider d'abandonner, la personne doit savoir si la culture est un terreau fertile pour son innovation. En revanche, vous laissez entendre qu'il faut ériger cette culture, être novatrice et audacieuse, et foncer. Une bien mince ligne, pouvez-vous nous en dire plus?

$D^{\text {re }}$ Olive Yonge : Oui, la ligne est mince. Revenons au moment où j'étais étudiante infirmière. . J'avais mon diplôme en soins hospitaliers, puis je suis revenue compléter mon baccalauréat en sciences. Durant mon premier programme, je n'ai pas mis de temps à comprendre que l'équilibre de l'unité de soins reposait sur les croyances, les valeurs, l'exemple et les directives de l'infirmière responsable ou de l'infirmière-chef. En tant qu'étudiante, on passait d'une unité à une autre, et l'on pouvait rapidement sentir les différences. Plus tard, étudiante à l'université, je travaillais occasionnellement comme infirmière volante. J'ai vite appris à demander si les clés de l'armoire à médicaments étaient cachées ou si quelqu'un les portait, ainsi que ce que l'on attendait de moi. Une fois de plus, j'ai décelé une grande différence d'une unité à l'autre, qui 
see all of me, but I don't see my back." That is a powerful metaphor for nursing. So, I will watch your back, I will guard your back, I will take care of your back. Sometimes that back is small, sometimes it is large, but I have to have you be my back.

Dr. Jacinthe Pepin: That is very nice. Have you had a chance to express all you wanted to say about innovation? Are there any other points you would like to add?

Dr. Olive Yonge: Society is innovating at a very fast pace. You just look at all the start-up companies, an example being Snapchat, an IOP was released last week at $\$ 17 /$ share and at the end of the day was trading at \$23. All this activity is taking place as we speak. For us, we too have to be innovating like society. I will give you another example: gaming. We need to think more about gaming. We have a faculty member who completed her doctorate in technology and leadership. She introduced gaming to teach nursing research. The students love that course. One, because she is using a gaming platform and the students can finish that course any time, when they complete enough "quests." It is all set up for student centered learning. When we think about innovation and technology, I think that it is one area that we are really going to have to think about more seriously. Second Life has millions of users, multiple economies it has spawned, and there are so many gamers involved. That is what we have to do... Innovation is already occurring out there, so maybe we do not innovate here, but for us it is innovation (gaming). We need to do or think about how they are learning in society so that we can also teach from the same perspective. Just a thought on the whole technology front and what is happening with technology. Really watch it carefully. Some of our students are engaged in and expect us to be experts in the area of technology.

Everything I am reading about blending is positive because you are not always in class, students are not always in class, but it is not cheaper than traditional teaching. People assume that technology is cheaper, but it is actually not. I think you have to engage in blended learning for other reasons. reposait sur le leadership. La direction des soins infirmiers de l'hôpital demeurait la même, mais les infirmières responsables d'unités variaient. Leur leadership s'exprimait de différentes manières. Lorsqu'il est question de culture pour une faculté de sciences infirmières, je crois que nous la créons toutes. Nous avons toutes du leadership, mais la direction du corps professoral est essentielle. La doyenne assure des conditions d'éventuel succès si nous échouons (louanger plutôt que blâmer) pendant le processus d'évaluation par le comité de pairs du corps professoral. S'il faut instaurer une culture d'innovation, les professeurs ont besoin d'orientation et de soutien. . Je crois que si l'équipe de direction d'une faculté a un état d'esprit d'avancement plutôt que fixe (Dweck, 2006), c'est là que l'innovation survient. Lorsque j'ai lancé le programme de préceptorat, j'avais la doyenne idéale pour appuyer mon idée. Elle a vu l'idée et elle a dit: «Vas-y, continue sur ta lancée. » Si elle m'avait plutôt dit que ça ne fonctionnerait jamais, que le corps professoral s'y opposait fortement, j'aurais tout arrêté. En d'autres mots, je n'aurais pas pu continuer sans son soutien ou celui de l'équipe de direction.

$D^{\text {re }}$ Jacinthe Pepin : Et ce serait là une raison pour abandonner?

\section{$D^{\text {re }}$ Olive Yonge : En effet.}

$D^{\text {re }}$ Jacinthe Pepin : Jusqu'ici, vous avez émis deux conseils quant à l'innovation : d'abord, de faire le travail préparatoire, et ensuite, de savoir quand on doit abandonner ou s'armer d'audace et continuer. Vous avez d'autres suggestions?

$D^{\text {re }}$ Olive Yonge : Soyez forte. Osez aller plus loin. Prenez des risques, et ne laissez pas la défaite vous décourager. En affaires, il y a des entrepreneurs qui ont tendance à échouer. Ceux qui ont beaucoup de succès se promènent constamment d'une idée à l'autre en répétant : «Et si...? Et si...? » D'une certaine manière, nous devons cultiver cette attitude dans notre profession. Poser davantage de questions, nourrir notre curiosité. Lorsque l'on génère une myriade d'idées, certaines s'avéreront des échecs, des ratés. Nous devons adopter une culture qui accepte ce constat, qui dit: «Continuez de questionner, de réfléchir», une culture de 
This morning, I read a story in our local newspaper about a grade eight teacher. He has turned his grade eight science classroom into a whole mythology. No tables, no desks. He is connected to a YouTube channel and has created a website, and he and his students are participating in all sorts of quests. Interestingly, what he is finding is that the girls are equally engaged as the boys which is a huge finding because we know we have to have more females in the STEMs and they already start making decisions for STEMs starting in grade nine through the courses they take in high school. And I thought, "Wow, this is so fantastic, engaging girls in science because the teacher is using a different type of pedagogy."

Dr. Jacinthe Pepin: This is really, really important to consider.

Dr. Olive Yonge: Yes, in nursing, we need to consider this. There is so much faculty development needed to keep up with the changes is society.

Dr. Jacinthe Pepin: And that is why you created the Faculty Learning Communities, as part of it?

Dr. Olive Yonge: Yes, it is. It is essentially lifelong learning. We were told it was going to be life-long learning, well, it is. We have to spend just as much time learning about pedagogy as we do research. You cannot just conduct researchyou have to understand pedagogy and what is occurring in pedagogy. You have to read the nursing education journals, attend the CASN conferences (thank goodness CASN is providing them). I really appreciate all the modules that CASN is offering. I really, really appreciate your journal-it is so good to have a place to disseminate what you are thinking and findingand I really appreciate the leadership that CASN is providing. It is a must for teaching and learning. soutien mutuel où personne ne cherche à faire la vie dure aux autres.

Nous devons ouvrir des portes les unes aux autres grâce au parrainage, au mentorat ou simplement en s'entraidant. C'est essentiel de démontrer de la gratitude ou de l'estime et de la reconnaissance aux membres du corps professoral qui vivent des difficultés. J'ai été chanceuse de travailler dans une unité de trentecinq personnes qui se dépassaient pour offrir de petits cadeaux, des encouragements et des petites pensées. Pas tous les jours, bien sûr, mais nous tentions toujours de protéger les arrières des autres, et peut-être avez-vous aussi été élevée avec cette philosophie, qui va comme suit: attardez-vous sur vos faiblesses. Si vous avez des forces, attardez-vous sur vos faiblesses. Eh bien, dans cette unité, ce n'est pas ce qu'on faisait; nous nous attardions uniquement sur nos forces. Il faut espérer que nos faiblesses, ou les choses que nous n'aimons pas faire, seront les forces des autres. Se concentrer seulement sur nos propres forces, j'ai vraiment trouvé cette attitude libératrice, car elle me permettait d'émettre des idées, de dire : «Et si...? Et si...?» Et j’étais soutenue par les réponses vraies de l'équipe : «Quelle bonne idée, Olive», ou «Ça ne fonctionnera pas, Olive, et voici pourquoi... » $\mathrm{Ce}$ à quoi je répliquais, en tout respect: «Oh, d'accord, très bien. Merci de ton commentaire. » Plutôt que de me laisser me jeter dans un gouffre, elles intervenaient pour me suggérer une route à suivre. Et j'en faisais autant pour les autres membres. Je voyais aussi des choses. Virginia Satir, une travailleuse sociale, a un jour dit : «Je me vois en entier, mais je ne vois pas mon dos. " C'est une métaphore puissante pour les soins infirmiers. Chacune surveille donc le dos de l'autre, le protège, en prend soin. Qu'il soit petit ou grand, ce dos a besoin de soutien.

$D^{\text {re }}$ Jacinthe Pepin : C'est très bien dit. Y a-t-il des éléments relatifs à l'innovation que vous n'avez pas eu l'occasion d'aborder? Souhaitezvous ajouter quelque chose?

$D^{\text {re }}$ Olive Yonge : La société progresse à un rythme effréné. Regardez seulement toutes ces entreprises en démarrage, notamment Snapchat, qui valait dix-sept dollars l'action à son 
ouverture sur les marchés et, à la fin de la journée, en valait vingt-trois. Tout ce mouvement se produit en ce moment même. Nous nous devons d'innover de la même manière. Je vous donne un autre exemple : les jeux vidéo. Nous devons y réfléchir davantage. Une membre de notre faculté a complété un doctorat en technologie et leadership, et a intégré les jeux dans l'enseignement de la recherche en sciences infirmières. Les étudiantes adorent ce cours. Premièrement, parce qu'elles se servent d'une plateforme de jeux, et deuxièmement, parce que les étudiantes peuvent finir ce cours à leur guise en réalisant un certain nombre de «quêtes ». C'est tout à fait adapté à l'apprentissage centré sur les étudiantes. En ce qui concerne la technologie en innovation, je crois que c'est un domaine auquel il faudra sérieusement réfléchir. Avec ses millions d'utilisateurs, l'univers virtuel Second Life a créé plusieurs économies et tellement de joueurs s'y consacrent. C'est ce que nous devons faire... L'innovation est déjà en cours; nous n'innovons peut-être pas ici, mais le jeu est tout de même une innovation à nos yeux. Nous devons penser à intégrer cette manière d'apprendre en société afin d'enseigner selon le même angle. Ce n'est qu'un petit rappel de ce qui se passe dans le domaine de la technologie. Il faut surveiller cela de près. Certaines étudiantes y sont impliquées et s'attendent à ce que nous soyons des spécialistes du domaine.

Tout ce que je lis à propos de l'intégration de la technologie est positif; l'enseignante et les étudiantes ne sont pas toujours en classe, mais ce n'est pas moins dispendieux que l'enseignement traditionnel. Les gens pensent d'emblée que la technologie réduit les coûts, mais ce n'est pas vraiment le cas. Je crois qu'il faut s'investir dans l'enseignement hybride pour d'autres raisons.

Ce matin, j'ai lu un article à propos d'un enseignant de huitième année dans le journal local. Il a carrément créé un mythe autour de sa classe de science. Aucune table, aucun pupitre. Il est connecté à une chaîne YouTube et a créé un site Web, où il participe à toutes sortes de quêtes en compagnie de ses élèves. Curieusement, il réalise que les filles s'impliquent autant que les garçons, ce qui est une grande découverte, car 
nous sommes conscientes qu'il faut attirer plus de femmes vers la science, la technologie, l'ingénierie et les mathématiques (STIM). D'ailleurs, elles prennent déjà des décisions liées à ces domaines dans leurs cours au secondaire. Et je trouvais cela si fantastique qu'en empruntant une pédagogie différente, l'enseignant a été en mesure de susciter l'intérêt des filles pour la science.

$D^{\text {re }}$ Jacinthe Pepin : En effet, ce n'est pas un point à prendre à la légère.

$D^{\text {re }}$ Olive Yonge : Tout à fait. En sciences infirmières, il faut prendre cela au sérieux. Le corps professoral doit continuer de se développer pour maintenir le rythme de transformation de la société.

$D^{\text {re }}$ Jacinthe Pepin : C'est l'une des raisons pour lesquelles vous avez mis sur pied les communautés d'apprentissage?

$D^{\text {re }}$ Olive Yonge : Effectivement. En somme, c'est un apprentissage à vie. C'est ce que l'on nous avait dit, et c'est la vérité. Il faut nous consacrer autant à l'étude de la pédagogie qu'à la recherche. Il ne s'agit pas uniquement de mener des recherches; il faut aussi comprendre la pédagogie et ses mécanismes, lire les revues sur la formation en sciences infirmières et participer aux conférences de l'ACESI (heureusement, l'organisme se charge de les organiser!) J'aime beaucoup tous les modules offerts par l'ACESI. Aussi, j'adore vraiment votre revue! Quel bonheur d'avoir un endroit où semer ses idées et ses découvertes. L'ACESI apporte également un leadership appréciable. C'est un joueur essentiel dans l'enseignement et l'apprentissage.

\section{References / Références}

Cox, M. (2013). The impact of communities of practice in support of early-stage academics. International Journal for Academic Development, 18(1), 18-30. doi:https://doi.org/10.1080/1360144x.2011.599600

Dweck, C. (2006) Mindset: The new psychology of success. New York, NY: Random House.

Kotter, J. P. (2012). Leading Change. Brighton, MA: Harvard Business Review Press.

Patton, M. Q. (2011) Developmental evaluation: Applying complexity concepts to enhance innovation and use. New York, NY: The Guilford Press.

Wenger, E. (1998). Communities of practice: Learning, meaning, identity. Cambridge, UK: Cambridge University Press. 